\title{
Laser Programs Facility Management Plan for Environment, Safety, and Health
}

G. E. Cruz

$$
\begin{aligned}
& \text { RECENPED } \\
& \text { AUS } 22 \text { iss } \\
& \text { OSTI }
\end{aligned}
$$

\section{MASTER}

January 1, 1996

This is an informal report intended primarily for internal or limited external distribution. The opinions and conclusions stated are those of the author and may or may not be those of the Laboratory.

Work performed under the auspices of the U.S. Department of Energy by the Lawrence Livermore National Laboratory under Contract W-7405-Eng-48.

\section{DISTRIBUTION OF THIS DOCUMENT IS UNLMATED}

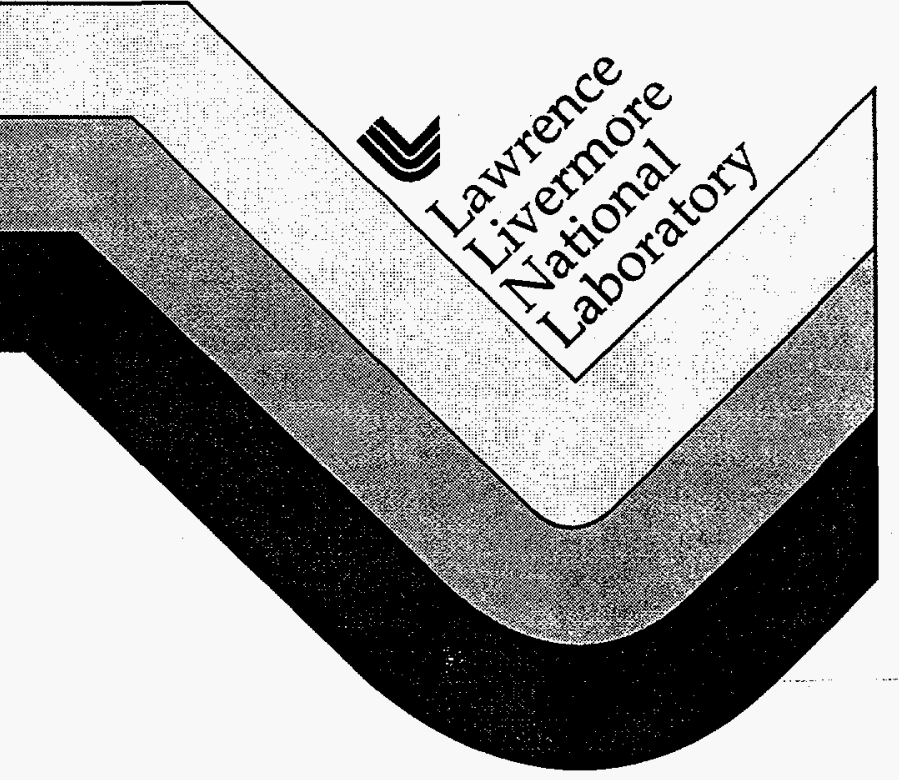




\section{DISCLAIMER}

This document was prepared as an account of work sponsored by an agency of the United States Government. Neither the United States Government nor the University of California nor any of their employees, makes any warranty, express or implied, or assumes any legal liability or responsibility for the accuracy, completeness, or usefulness of any information, apparatus, product, or process disclosed, or represents that its use would not infringe privately owned rights. Reference herein to any specific commercial product, process, or service by trade name, trademark, manufacturer, or otherwise, does not necessarily constitute or imply its endorsement, recommendation, or favoring by the United States Government or the University of California. The views and opinions of authors expressed herein do not necessarily state or reflect those of the United States Government or the University of California, and shall not be used for advertising or product endorsement purposes.

This report has been reproduced directly from the best available copy.

Available to DOE and DOE contractors from the Office of Scientific and Technical Information

P.O. Box 62, Oak Ridge, TN 37831

Prices available from (615) 576-8401, FTS 626-8401

Available to the public from the National Technical Information Service

U.S. Department of Commerce

5285 Port Royal Rd.

Springfield, VA 22161 


\section{Laser Programs Facility Management Plan for Environment, Safety, and Health}

Approved by:

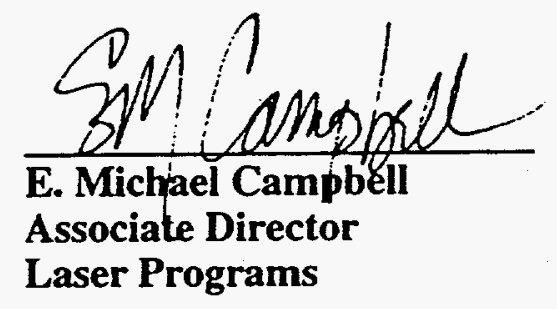

LAWRENCE LIVERMORE NATIONAL LABORATORY

University of California/Livermore, California 
$=$ 


\section{DISCLAIMER}

Portions of this document may be illegible in electronic image products. Images are produced from the best available original document. 



\section{Laser Programs Facility Management Plan for Environment, Safety, and Health}

\section{A. Policy Statement}

The Laser Programs basic environment, safety, and health (ES\&H) policy is: to take every reasonable precaution in the performance of its work to protect the health and safety of employees and the public; to minimize the possibility of damage to property and the environment. The responsibility for safety resides with the Associate Director (AD) for Laser Programs and is delegated through line management to each employee. The Hazards Control, Health Services, and Environmental Protection Departments support the Programs with technical services and professional safety expertise.

This Facility Management Plan (FMP) provides the basis for the rules and practices that are necessary for efficient and safe conduct of operations in the Laser Programs Complex. Everyone who enters this complex, in whatever capacity, is expected to abide by the applicable requirements of this Plan. All employees are expected to protect themselves and others from injury. Regular occupants of the complex are expected to guide and govern visitors and to assist new or temporary occupants in understanding and obeying applicable requirements.

\section{B. Review and Approval Authority}

\section{B.1 Review}

This FMP shall be formally reviewed annually by the Laser Programs Safety Officer and at least triennially by the AD for Laser Programs to ensure that its contents are appropriate and adequate for current operations. If changes are necessary before the triennial review date, the FMP will be amended and the changes approved by the Associate Director for Laser Programs.

The Facility Management Plan was prepared by:
G. E. Cruz
Safety Officer, Laser Programs

The Facility Management Plan has been reviewed by:
E. V. George
Principal Deputy Associate Director, Laser
R. M. Feinberg
Programs
W. E. Krupke
Deputy Associate Director, Laser Programs
C. W. Hatcher
Deputy Associate Director, Laser Programs
M. G. Trent
H. T. Powell
J. D. Kilkenny
Assurances Manager, Laser Programs
Hazards Control ES\&H Team Leader
J. A. Paisner
Laser Science and Technology Program
Target Physics Program
J. T. Early
National Ignition Facility Project Manager
R. E. Twogood
Isotope Separation and Advanced Manufacturing Program
N. M. Ceglio
Imaging and Detection Program
L. Chandler
Microtechnology Program
K. H. Nakamura
Assessment Officer, Laser Programs
Operations Manager, Laser Programs 


\section{B.2 Approval}

This FMP has been approved by:
E. Michael Campbell
Associate Director, Laser Programs

\section{Introduction}

\section{C.1 General Information}

The Lawrence Livermore National Laboratory's (LLNL) Laser Programs ES\&H policy is established by the Associate Director for Laser Programs. This FMP is one component of that policy.

Laser Programs personnel design, construct and operate research and development equipment located in various Livermore and Site 300 buildings (see Appendix A). The Programs include a variety of activities, primarily laser research and development, inertial confinement fusion, isotope separation, and an increasing emphasis on materials processing, imaging systems, and signal analysis.

This FMP is a formal statement of responsibilities and controls to assure operational activities are conducted without harm to employees, the general public, or the environment. This plan identifies the hazards associated with operating a large research and development facility and is a vehicle to control and mitigate those hazards. Hazards include, but are not limited to: laser beams, hazardous and radioactive materials, criticality, ionizing radiation or $\mathrm{x}$ rays, high-voltage electrical equipment, chemicals, and powered machinery.

\section{C.2 Changes}

Proposed changes in operations that are outside of the scope of this FMP will be reviewed and approved as described in Section D prior to initiating changes.

\section{Responsibility and Authority}

\section{D.1 Associate Director}

The AD for Laser Programs is responsible for the conduct of all activities within Laser Programs. Through Program Leaders (PLs), he or she provides management direction to those people responsible for individual tasks. Through the Assurances Office, he or she monitors activities to assure that they are conducted in accordance with LLNL ES\&H policies and procedures. This program is in conformance with the environment, safety and health program at Lawrence Livermore National Laboratory, UCRL-AR-119618 Rev. 0.

The AD approves this FMP, all Facility Safety Procedures (FSPs), and all Level A Operational Safety Procedures (OSPs) that involve a high level of risk as defined in Appendix 2-D (Level A) of the LLNL Health \& Safety Manual. The AD approves all program-wide activity plans, such as quality assurance and self-assessment plans. 


\section{D.2 Program Leader (PL)}

\section{D.2.1 Program}

The Program Leader of a specific program has cognizance over all activities within that program. Through the Associate Program Leaders (APLs) and other line managers, he or she provides direction to Lead Experimenters (LEs) and Responsible Individuals (RIs) regarding the goals and requirements of their activities. The PL allocates resources within his or her program to assure that both program and ES\&H goals and requirements are met.

PLs, or their designee approve all Level B OSPs as defined in Appendix 2-D of the LLNL Health \& Safety Manual.

\section{D.2.2 Assurances}

The Assurance Manager for Laser Programs provides support to program management to assist them in maintaining safe, healthy, and environmentally sound working conditions. This includes:

- preparation of program-wide ES\&H plans;

- assisting program staff in setting up activities that support those plans;

- reviewing all program ES\&H procedures;

- monitoring program activities to assure that they are in compliance with program and Laboratory requirements; and

- providing an interface between the programs and external ES\&H organizations.

\section{D.2.3 Operations}

The Manager for Laser Programs Operations provides, among other services, facilities support to program activities. Operations serves as a point of contact between the programs and Plant Engineering Department to maintain and modify those facilities as required to meet programmatic and ES\&H requirements.

\section{D.3 Lead Experimenters and Responsible Individuals}

The LEs and RIs are those people who have been given responsibility for a specific laboratory, shop, or activity within Laser Programs. They shall assure that:

- all activities within their area are conducted in accordance with applicable OSPs, FSPs, and Laboratory policy;

- all personnel working in their area have the necessary training, experience, and equipment to perform their jobs safely;

- work areas are maintained in a safe, orderly, and organized manner; and,

- the documentation needed to achieve and verify these goals and requirements are maintained in a readily retrievable manner. 


\section{D.4 Individuals}

Each individual working within Laser Programs is responsible for maintaining safe, healthy, and environmentally sound working conditions in their area. No individual is to undertake any activity that involves a significant risk to themselves, their coworkers, Laboratory facilities, the public, or the environment. If individuals have any question regarding their responsibilities while conducting their work, they should check with their supervisor, other line management, EPD Analyst, or Hazards Control staff, before starting. Each individual has the responsibility to stop high-risk activities under his or her supervision. Each individual also has the responsibility to ask management, EPD, or Hazards Control to stop a high-risk activity in any area of Laser Programs.

\section{D.5 ES\&H Support Departments}

The Hazards Control, Environmental Protection, and Health Services Departments are responsible for providing expertise, guidance, and services to Laser Programs in the areas of environment, safety, and health. In Laser Programs, Hazards Control ES\&H Team 2 coordinates safety, environment, and health services. ES\&H Team 2 is composed of a staff of environmental and safety disciplines, health and safety technicians, a team leader, deputy team leader, and administrative staff.

Environment, safety, and health disciplines are assigned to various portions of Laser Programs as required. They advise experimenters and other personnel on safety, health, and environmental issues in the workplace. Discipline activities include:

- safety and environmental inspections;

- evaluating new experiments and procedures;

- reviewing designs for facilities and equipment;

- preparing NEPA documentation;

- reviewing and contributing to safety and environmental assessments;

- designing programs for, and reviewing the results of, personnel and facility monitoring programs;

- evaluating lessons to be learned from accidents, incidents, and occupational-related illnesses;

- assisting with air- and water-discharge permitting;

- packaging and preparing requisition for hazardous waste;

- assisting with emergency response to accidents, fires, spills, and other incidents;

- provide training; and

- through input to OSPs and FSPs, establishing special controls needed to address special safety issues not covered by the LLNL Health \& Safety Manual and the Environmental Compliance Manual. 
Environment, safety, and health disciplines attached to ES\&H Team 2 are professionals in the fields of:

\author{
Discipline \\ - Health Physics \\ Field of Knowledge \\ - Industrial Hygiene Chemical safety, non-ionizing radiation, heat \\ stress, noise and sanitation \\ - Fire Protection \\ Fire safety engineering \\ - Explosive Safety \\ - Criticality Safety \\ Explosives safety \\ - Industrial Safety \\ safety, and vehicles \\ - EPD Analyst \\ Fissile material safety \\ Lasers, electrical, pressure, construction \\ Environmental compliance
}

These disciplines are supported by analytical laboratories, instrument calibration, radiation and chemical dosimetry, respirator services, and filter testing services.

The Emergency Management Division (Fire Department) of Hazards Control provides life-saving and fire-fighting services to all of LLNL. The Division also performs building fire inspections and sprinkler testing, and issues on-site burn permits.

Health and Safety Technicians are assigned to field locations throughout Laser Programs. Under the direction of a technician supervisor, they perform day-to-day activities necessary to support the safety program. They will assist program personnel in such activities as:

- monitoring for ionizing radiation, sound, environmental releases and chemicals;

- checking for oxygen deficiency and toxic gas during confined space entry;

- controlling roof access;

- emergency response;

- safety tours;

- assisting with disposal of hazardous waste;

- maintenance of safety equipment; and

- inspections.

Telephone numbers for technicians are posted throughout their areas of responsibility, or they can be reached through the ES\&H Team 2 office (2-6126).

The ES\&H Team 2 administrative staff directs the efforts of the disciplines and health and safety technicians and acts as an information conduit for program support requests. In addition, the team staff coordinates the review and production of OSPs and FSPs and distributes and collects design review packages. The team leader is also charged with recommending the level of Hazards Control and Environmental Protection support needed by Laser Programs. 
Programs Training Plan establishes the policies and assigns responsibilities for the management and conduct of training activities in the directorate. This training plan is consistent with LLNL policies and procedures. This plan applies to the research, technology development, and deployment activities of all programmatic elements under the direction of the Associate Director for Laser Programs, as well as all visitors and personnel who support operations within the programs.

\section{G. Emergency Response}

The philosophy of emergency preparedness at LLNL relies upon the use of the individual on-site organizations' capabilities and resources to protect the welfare of the employees. It is based upon the realization that during a major disaster, outside help may not be immediately available.

As a direct result of this philosophy, a Self-Help Program was implemented at LLNL. The two documents that describe emergency preparedness and self-help in the Laser Programs are: Emergency Preparedness and Response Plan for Laser Programs, and Disaster Preparedness Plan for Individuals. These two documents serve to integrate Laser Programs actions with the overall LLNL Emergency Plan. The approach of the Programs is to provide a flexible plan of action to ensure that: (1) emergency first aid is provided to injured personnel; (2) that the safety of others, both on- and off-site, is ensured; and (3) additional damage to facilities is minimized.

Everyone who enters the complex, in whatever capacity, is required to follow the applicable guidance and procedures as outlined in the emergency preparedness documents. Regular occupants are expected to guide and govern visitors and to assist new or temporary occupants in complying with the guidance provided in the Laser Programs emergency preparedness documents.

\section{H. References}

LLNL Health \& Safety Manual, Health and Safety Division, Hazards Control Department, M-010.

Environmental Compliance Manual (UCRL-MA-118090), Environmental Protection Department.

Laser Programs Training Plan (L-12666), Laser Programs Assurances Office, Laser Programs.

Emergency Preparedness and Response Plan for Laser Programs (L-15409), Laser Programs Assurances Office, Laser Programs.

Disaster Preparedness Plan for Individuals (L-15437), Laser Programs Assurances Office, Laser Programs.

LLNL Emergency Preparedness Plan, Emergency Preparedness and Response Program. 



\section{Appendix A}

\section{Laser Programs Facilities}

\begin{tabular}{|c|c|c|}
\hline Building Number & Facility Name & Program Occupants \\
\hline 005 & Graham Court & ICF/PE/WE \\
\hline 160 & Cavatron Building & $\overline{I S A M}$ \\
\hline 162 & Research/Crystal Growth & ICF/NAI \\
\hline 164 & Preparation/Lasers & ICF \\
\hline 165 & O.P.R.L & $\overline{I C F}$ \\
\hline $165 \mathrm{~A}$ & 165 Annex & \\
\hline 166 & Development Lab & ISAM/ICF/EP/NAI \\
\hline 168 & Research & ICF/NAI \\
\hline 169 & Development Lab & $\mathrm{ICF} / \mathrm{EE}$ \\
\hline 169 & Block House & ICF/EE \\
\hline $169 \mathrm{~A}$ & Paint Booth & ICF/EE \\
\hline $169 \mathrm{~B}$ & Saw Shop & ICF/EE \\
\hline $169 \mathrm{C}$ & $\begin{array}{l}\text { Saw Shop } \\
\end{array}$ & $\mathrm{ICF} / \mathrm{EE}$ \\
\hline 171 & Development Lab & ICF/AMP/P\&ST \\
\hline 174 & Research & ICF/P\&ST/CHEM \\
\hline 175 & Mars Facility & ISAM \\
\hline 176 & Machine Shop & $\mathrm{ICF}$ \\
\hline 177 & Development Lab & $\overline{\text { ISAM }}$ \\
\hline 179 & Development Lab & AMP \\
\hline 272 & E/O Development Lab & I\&DP/EP \\
\hline OS273 & Line of Site Vault & ISAM \\
\hline 298 & Fusion Target & ICF/NAI \\
\hline 335 & Support Facility & ISAM/DSED \\
\hline 381 & Office/Research & ICF/OPS \\
\hline 382 & Research & $\overline{\mathrm{ICF}}$ \\
\hline 383 & Machine Shop & MMED \\
\hline 391 & Nova & ICF/AMP \\
\hline 392 & Maintenance Shop & ICF \\
\hline 394 & Chemical Storage & $\overline{\mathrm{ICF}}$ \\
\hline 423 & ARC & I\&DP/ICF \\
\hline 481 & Office & $\overline{\mathrm{ICF} / \mathrm{I} \& \mathrm{DP} / \mathrm{NAI}}$ \\
\hline 482 & Office & ISAM/ME/EE/USEC/LD/NAI \\
\hline 490 & Demonstration Facility & ISAM/OPS \\
\hline 491 & Refurb Facility & $\overline{\text { ISAM }}$ \\
\hline 492 & Dye Pump Facility & ISAM \\
\hline 493 & Separator Support Facility & $\overline{\text { ISAM }}$ \\
\hline 494 & Laser Assembly & ISAM \\
\hline 531 & Test Stand & I\&DP \\
\hline 865 & Advanced Test Accelerator & OPS \\
\hline F27 Hangar & Aircraft Hangar & I\&DP \\
\hline 1601 & ME Techs & ICF/NAI \\
\hline 1602 & Electronics Fab. & ICF/EE \\
\hline
\end{tabular}




\begin{tabular}{|c|c|c|}
\hline \multicolumn{3}{|c|}{$\begin{array}{c}\text { Appendix A (Cont'd.) } \\
\text { Laser Programs Facilities }\end{array}$} \\
\hline Building Number & Facility Name & Program Occupants \\
\hline 1678 & ICF Offices & ICF/NAI \\
\hline 1725 & EE Tech. Support & $\overline{\mathrm{ICF}}$ \\
\hline 1727 & Tech. Support & AMP \\
\hline 1736 & Tech. Support & ISAM/NAI \\
\hline 1738 & Technology & OPS \\
\hline 2775 & Offices & AMP \\
\hline 2801 & Student Lab & DAS \\
\hline 2802 & Lab & DAS \\
\hline 2804 & Office & AMP \\
\hline 2825 & Office & OPS \\
\hline 3724 & Y Division Offices & OPS/ICF \\
\hline 3725 & Y Division Offices & ICF/OPS/I\&OP \\
\hline 3726 & Office & ICF \\
\hline 3751 & Hazards Control/Y Div. & HC ES\&H Team \\
\hline 3777 & Y Div. Offices & DOE \\
\hline 3903 & Glass Depot & $\mathrm{ICF}$ \\
\hline 3904 & E Tech. Support & $\mathrm{ICF}$ \\
\hline 3905 & Test Lab/Draft & ICF \\
\hline 3906 & Tech Support & $\mathrm{ICF}$ \\
\hline 3907 & E Tech Support & ICF \\
\hline 3925 & Y Div. Conference Room & ICF/OPS \\
\hline 3926 & Y Div. Offices & ICF \\
\hline 3981 & Y Div. Offices & ICF \\
\hline 3982 & Y Div. Offices & ICF \\
\hline 5925 & Tech Support & ISAM \\
\hline 5926 & Tech Support & HR \\
\hline 5976 & Computer Support & ISAM \\
\hline 5977 & Offices & ISAM \\
\hline 5 & Offices & ISAM \\
\hline \begin{tabular}{|l|}
5981 \\
\end{tabular} & Offices & ISAM \\
\hline 5982 & Offices & ISAM \\
\hline 5983 & Offices & ISAM \\
\hline 5984 & Offices & ISAM \\
\hline 5985 & Offices & ISAM \\
\hline 4297 & Tent & I\&DP \\
\hline 4299 & Tent & OPS \\
\hline \begin{tabular}{|l|}
5399 \\
\end{tabular} & Tent & I\&DP \\
\hline
\end{tabular}

